\title{
Evaluation of Xa7 Introgressed Lines Against Bacterial Leaf Blight (BLB) Disease and Their Agronomic Performances
}

\author{
Siti Norhidaya Yazid \\ UPM \\ Mohd Bahagia Ab Ghaffar \\ MARDI: Institut Penyelidikan dan Kemajuan Pertanian \\ Shahril Ab Razak \\ MARDI \\ Zuraida Abd Rahman \\ MARDI \\ Kogeethavani Ramachandran \\ MARDI \\ Habibuddin Hashim \\ MARDI: Institut Penyelidikan dan Kemajuan Pertanian \\ Siti Nor Aziemah Mohamad \\ Universiti Sains Malaysia \\ khairulmazmi Ahmad ( $\square$ khairulmazmi@upm.edu.my ) \\ Universiti Putra Malaysia
}

\section{Research article}

Keywords: Oryza sativa L, Bacterial leaf blight, Backcrossing, Marker-assisted selection, Xa7 gene

Posted Date: December 1st, 2020

DOI: https://doi.org/10.21203/rs.3.rs-113691/v1

License: (c) (i) This work is licensed under a Creative Commons Attribution 4.0 International License. Read Full License 


\section{Abstract}

Bacterial leaf blight (BLB) is one of the major rice diseases in Malaysia. The disease can potentially cause a 30 to $50 \%$ yield loss to the rice crop. Hence, the utilization of resistant rice varieties to BLB is a crucial approach to prevent potential yield loss and to ensure the sustainability of the rice industry in Malaysia. This study aims to incorporate BLB resistant trait into a susceptible, high yielding, popular commercial variety MR219. The identified donor parent is IRBB7, harboring Xa7, a broad-spectrum BLB resistant gene which closely linked to two STS markers, the ID7 and ID15. Backcrossing was initiated, using IRBB7 as the donor and MR219 as the recurrent parents. Marker-assisted selection (MAS) was applied to monitor and confirm the introgression of $\mathrm{Xa}$ 7 in the progenies of the cross based on alleles produced by the markers. We managed to generate $19 \mathrm{BC}$ F 4 lines harboring homozygous Xa7 gene that were phenotypically resistant when challenged with Xanthomonas oryzae pv. oryzae through an artificial inoculation. The improved lines exhibited similar morphological and yield performance of the recurrent parent. Two lines, PB-2-107 and PB-2-34 were identified for their outstanding performances which are comparable to MR219. This study demonstrates the advantage of MAS application in the improvement of disease resistance traits in the elite rice cultivars.

\subsection{Introduction}

Rice (Oryza sativa L.) is always known to be at the frontline in the effort towards solving the world hunger problem as it is the second most widely grown cereal crop in the world (Siwar et al., 2014). Approximately, 3.5 billion world populations are depending on rice as their main source of food. However, rice production in Malaysia contributed to only $0.37 \%$ of the total 499.07 million tons of world rice production, but it managed to support $72.850 \%$ of the targeted national self-sufficiency level for rice (Asfaliza, 2019; United States Department of Agriculture, 2020). Rice variety MR219 is a variety released for commercial cultivation in 1999 (Alias et al., 2001). It was widely grown in the country, covering more than 90\% of Malaysia's rice granary areas (Zainuddin et al., 2012). The popularity of the variety is due to its high yielding potential, capable of producing as high as $8319 \mathrm{~kg} / \mathrm{ha}$ in the farmers' fields (Elixon et al., 2017; Shamsudin et al., 2016). However, this productivity potential is threatened with $30-50 \%$ potential loss due to bacterial leaf blight (BLB) disease infection (Shamsudin et al., 2019). BLB is a known pathogenic bacterial-borne disease caused by Xanthomonas oryzae pv. oryzae (Xoo) (Chukwu et al., 2019;

Mew et al., 1982). The disease was first discovered by the Japanese in 1884 (Tagami and Mizukami, 1962). Malaysia's tropical weather with continuity of shade, flood, and rainfall throughout the year favored BLB infection. These conditions availing bacterium transmission through the splashing or windblown rain, plant to plant contact, and through irrigation water movement. In rice production, BLB invasion occurred via wound cells caused by injuries transpired during handling, insect attack, or through natural openings like stomata. The established infection leads to noticeable lesions on leaf surface which reduce the green leaf area, resulting in the reduction of photosynthesis rate, blockage of nutrient and water supply, and increase transpiration rate of the plant (Shamsudin et al., 2019), which later promoting the cell death and desiccation of dying tissue (Lindenthal, Steiner and Oerke, 2005).

Management of BLB in the field is made feasible by using several methods including the use of bactericides, biological control, manipulation of cultural practices, and by using resistant varieties. The use of resistant varieties was introduced in many parts of the world including Malaysia. To date, more than 40 resistant genes have been identified which confer resistance to different BLB strains. Among them, 11 genes had been cloned, namely Xa1, Xa3/Xa26, Xa4, xa5, Xa10, xa13, Xa21, Xa23, xa25, Xa27, and Xa41 (Chukwu et al., 2019; Jiang et al., 2020). Xa7is a dominant resistant gene, first identified in rice cultivar DV85 (Accession number 8839 of the International Rice Research Institute) (Sidhu et al., 1978). The Xa7gene from DV85 was then transferred through backcrossing using IR24 as the recurrent, and a near-isogenic line (NIL) IRBB7 with Xa7 was developed (Chukwu et al., 2019 ; Ogawa et al., 1991). Xa7 gene has broad-spectrum resistance against various BLB strains (Jiang et al., 2020; Zhang et al., 2009). This gene is one of the most durable available resistant genes (Cruz et al., 2000). Moreover, Xa7 is more efficient at high temperatures, while others are less effective (Jiang et al., 2020; Webb et al., 2010). Thus, it may then be suitable for incorporation into Malaysian elite rice varieties as Malaysia typically experiences high temperatures of above $32^{\circ} \mathrm{C}$.

The Xa7gene has been fine mapped on chromosome 6 of rice (Webb et al., 2010). The gene is closely linked to two simple tagged sequences (STS) markers, ID7 and ID15 (Zhang et al., 2009). The availability of close-linked markers may facilitate marker-assisted selection (MAS) in the backcrossing programs. Application of MAS may accelerate the backcrossing process by reducing the number of backcrosses required to recover the recurrent plant genotype. Chen et al (2000) reported the first successful introgression of the BLB resistant gene into Chinese hybrid rice parents by using a combination of conventional and molecular approaches, creating positive acceptance of MAS application in the rice breeding (Chen et al., 2008; Hasan et at., 2015). Therefore, MAS can be utilized in the screening and monitoring of the introgressed gene in the breeding population and lines. Hence, the objectives of this study are to introgress the Xa7gene into an elite Malaysian rice cultivar, MR219 through series of backcrossing with the application of MAS as a tool. And to validate the resistance of developed lines against BLB infection and to assess the agronomic performance of those advance generation lines.

\subsection{Materials And Methods}

\section{Pure culture of Xoo and evaluation of parents' resistance level}

Pure culture of the causal pathogen, Xanthomonas oryzae pv. oryzae (Xoo), isolate MX01410, which represent the dominant pathotype in Peninsular Malaysia was obtained from MARDI Seberang Perai in Pulau Pinang. The inoculum suspension was prepared for artificial inoculation using 48 hr old 
Xoo culture at a concentration of $108 \mathrm{cfu} / \mathrm{mL}$ at OD600 $=0.1$. Parental rice varieties IRBB7 and MR219, as well as the other control varieties, MR263 and MR220CL2 were planted in the glasshouse located at MARDI Seberang Perai. Each test materials were planted as a single seedling per point with the distance of $0.25 \mathrm{~m} \times 0.25 \mathrm{~m}$ to one another using randomized completely block design (RCBD) with 3 replicates. The plants were regularly maintained. The crops were fertilized with 100: 75: $103 \mathrm{~kg} / \mathrm{ha}$ of N, P205, K2O. Insecticide was applied whenever necessary. The inoculation was done during the period from September 2018 to November 2018, by using the leaf clipping technique as described by Mew et al.,1982 (Mew, Cruz and Reyes, 1982 ). The tip of rice leaves $(2$ to $3 \mathrm{~cm}$ ) of 40-day old rice was cut with a scissor dipped into Xoo bacterial suspension. The inoculated leaves were evaluated at 3,5 , $7,9,11,14,17,19,21,23,25,27$ and 30 days after inoculation. The infected leaves were rated according to lesion length (cm) as described in the Standard Evaluation System for Rice, 2013 (IRRI, 2013).

\section{Plant DNA isolation and molecular analysis}

The leaves of the BC3F3 plants were sampled at the young stage on the 30 days after sowing and stored in a -20oC deep freezer for long-term storage. These plant materials were then used for DNA extraction using TacoTM plant DNA/RNA extraction kits (GeneReach, Taiwan). The extracted DNA was diluted to $50 \%$ with elution buffer before the polymerase chain reaction (PCR) procedure. The PCR reaction mixture (10 $\mu$ l) containing $1 \mu$ l of $50 \mathrm{ng} / \mu \mathrm{l}$ DNA template, $1 \mu \mathrm{l} 10 \mathrm{X}$ buffer, $1 \mu \mathrm{l}$ of dNTPs, $0.5 \mu \mathrm{l}$ of $25 \mathrm{mM} \mathrm{MgCl} 2,6 \mu \mathrm{l}$ of nucleus-free water, $0.1 \mu \mathrm{l}$ of Taq DNA polymerase and $0.4 \mu \mathrm{l}$ of $10 \mu \mathrm{M}$ for each forward and reverse primers were prepared. Two polymorphic tightly linked markers namely ID7 (F:ATATTCACCAAATGATTCCCTG, R:

ATACAAGCCTA AACCCATCTCA) and ID15 (F:ATACAGTGCCAATGATGAGGAG, R: CATACGAAACCCAACAGAAATAG) were used to detect the presence of $X a 7$ gene in the introgressed lines. (Zhang et al., 2009) The PCR amplification was performed using a thermocycler (Eppendorf Mastercycler gradient) as following this thermal cycling condition: pre-denaturation at $94^{\circ} \mathrm{C}$ for $4 \mathrm{~min}$; then followed by 35 cycles of denaturation at $94^{\circ} \mathrm{C}$ for 30 sec, annealing at $54.80 \mathrm{C}$ (ID7) or $44.60 \mathrm{C}$ (ID15) for $45 \mathrm{sec}$, extension at $720 \mathrm{C}$ for $1 \mathrm{~min}$ and final extension at $720 \mathrm{C}$ for 1 min. The PCR products were then fractionated in $2 \%(\mathrm{w} / \mathrm{v}) 1 \mathrm{X}$ TBE agarose gels by electrophoresing at $80 \mathrm{~V}$ for $45 \mathrm{~min}$ in $1 \mathrm{X}$ TBE running buffer (Khan et al., 2015; Zhang et al., 2009). Then, the gel was photographed under ultraviolet light Biorad Gel Imager. A 100 bp DNA ladder was used as a reference size for the allele sizes of the amplified product. The allele size scoring was performed based on the size of control positive (IRBB7) and control negative (MR219) parents. The progenies with the same allele size with IRBB7 were scored as harboring resistant allele (R allele) meanwhile progenies with the allele size of MR219 were scored as harboring susceptible allele (S allele).

\section{Development of Improved-MR219 resistant lines}

Rice variety IRBB7 (harboring Xa7gene) was used as the donor parent and MR219 (BLB-susceptible) was used as a recurrent parent. Markers were used to tag the Xa7 gene by using two STS markers namely ID7 and ID15. The crossing between MR219 and IRBB7 was initiated to produce the F1 seeds. The F1 seeds were then planted, genotyped, and selected for used as a female parent to be backcrossed with the recurrent parent to produce BC1F1 seeds. The BC1F1 seeds were planted, genotyped, and assessed for high similarity or closeness with the recurrent parent phenotypes before being backcross with MR219. Similar cycles of backcrossing, genotyping, and phenotypic assessments were followed until BC3F1 seeds were obtained. The selected BC3F1 individuals were allowed to be self-pollinated to produce BC3F2 seeds. The BC3F2 plants were genotyped and selected for further generation advancement until homozygous BC3F4 lines were identified. Nineteen BC3F4 lines with the Xa7gene and two others without the gene were subsequently used in the subsequent studies.

\section{Assessment of BLB resistance of the BC3F3 lines}

All 21 BC3F3 lines seeds and parents were sown and planted for an assessment on their resistance against BLB infection. The experiment was conducted in a glasshouse at MARDI Seberang Perai, during the period from November 2018 to January 2019. The experiment was in a RCBD design with three replicates. Each replicate is represented by 10 plants per line, grown and arranged in trough box in the glasshouse. Inoculation was done as previously described. Lesion length $(\mathrm{cm})$ was recorded after 25 DAl. The resistance level was categorized based on lesion length, as follow: $1-5 \mathrm{~cm}$ (Resistant, R), 5-10 cm (Moderately Resistant, MR); 10-15 cm (Moderately Susceptible, MS), > $15 \mathrm{~cm}$ (Susceptible, S), a classification class based on Standard Evaluation System of Rice (IRRI, 2013). Seeds of these plants were harvested as BC3F4 lines.

\section{Agronomic performance of BC3F4 line}

The field evaluation on the agronomic performance of the BC3F4 lines was carried out in the experimental plot at MARDI, Seberang Perai during the main season from January 2019 to March 2019. Seedlings at 20-25 days old age were transplanted as a single seedling per hill in a randomized completely block design (RCBD) with three replicates. The plot size was $4 \mathrm{~m} \mathrm{x} 4 \mathrm{~m}$, with $0.25 \mathrm{~m} \times 0.25 \mathrm{~m}$ per planting distance. The crops were fertilized with 100:75:103 kg/ha of N, P2O5, K2O. Ten agronomic characteristics were evaluated according to the Standard Evaluation System of rice (IRRI, 2013). The characteristics investigated comprised of tiller number/plant, plant height (cm), panicle number/plant, days to $80 \%$ maturation, panicle length (cm), spikelet number/panicle, filled grains/panicle, 1000-grains weight $(\mathrm{g})$, plant yield (g/plant) and yield based on crop cutting test (CCT) from $2 \times 2$ meter per plot (kg/ha). 


\section{Statistical analysis}

Observed data were subjected to analysis of variance (ANOVA) using the Statistical Analysis System (SAS 9.4). The means were compared using Duncan's Multiple Range Test (DMRT) to determine significant differences between tested varieties or lines at $5 \%$ probability for both disease assessment and agronomic performance studies. The relationship between agronomic characteristics and plant yield were then analyzed using simple correlation analysis.

\subsection{Results}

\section{Resistance of parental varieties to BLB}

BLB causing organism, the Xanthomonas oryzae oryzae (Xoo) isolate MX01410 from MARDI Seberang Perai, representing the dominant pathotype was used to evaluate the resistance of parental varieties to the disease. The lesion length after been inoculated was used as the parameter for classification of disease resistance level. Data was first recorded after three days of post-inoculation (DAl) and was continually assessed at every two days interval over 30 days period. Lesion length on the two parental varieties, IRBB7 and MR219 as well as two other control varieties (MR263 and MR220CL2) was summarized in Fig. 1.

Symptom of infection at the cut region on the leaves started to develop at variable length just after 5 DAl. Difference in lesion length between the highly susceptible variety (MR263) and the other varieties could be distinctly observed at 14 DAl. The lesion length on MR263 was about $14.2 \mathrm{~cm}$, almost double the length of other varieties. After $25 \mathrm{DAl}$, the difference in lesion length was more significant, bigger, and distinct. The lesion length on MR219 (moderately susceptible, MS) was about $12.90 \mathrm{~cm}$ as compared to the lesion length of IRBB7 (highly resistant, HR) of only $1.99 \mathrm{~cm}$. Figure 2 showed differential leaf response of the respective varieties at 14 DAl. The study showed the insignificant presence of a lesion on the inoculated leaf of IRBB7, while the lesion lengths on other varieties were of variable lengths, confirming the high resistance of IRBB7 as compared to other varieties. The degree of resistance of IRBB7 was followed in the order of MR219 < MR220CL2 <MR263.

\section{Development of the BC3F3 population.}

Backcrossing between IRBB7 and MR219 was initiated to transfer the Xa7gene from IRBB7 into progenies of the cross. The presence or absence of the gene in the plants was indicated by observing the alleles of the PCR products generated by the STS markers linked to the genes. Polymorphisms of the markers on the parental varieties are very distinct. The pattern of the generated alleles was presented in Fig. 3. Marker ID7 generated an allele size 653 bp on rice variety IRBB7 (lane R) and an S allele size 410 bp on MR219 (lane S). Marker ID15 generated two allele sizes 449 bp (R) and 414 bp (S), respectively. Plants having alleles $\mathrm{R}$ and $\mathrm{S}$ are plants which are with or without the Xa7gene, respectively and plants with RS alleles are heterozygous. During the development, only plants with the targeted $\mathrm{Xa} 7 \mathrm{gene}$ and having phenotypic characteristics closer or almost similar to the recurrent parent, MR219 were selected for further generation advancement until homozygous BC3F4 lines were developed and identified. a total of nineteen BC3F4, introgressed lines having homozygous 'R' allele of the Xa7 gene (Lanes 1, 2, 3, 4, 5, and others) and two other BC3F4, lines with the 'S' allele (Lanes 20 and 21) were identified

\section{The resistance of BC3F3 lines to Xanthomonas oryzae pv. oryzae.}

The efficacy of R-gene, Xa7 introgressed into the BC3F3 lines to express resistance against BLB infection was evaluated by challenging them against isolate MX01410, a prevalent Xoo pathotype. Based on the plotted line graph in Fig. 1, the plants' response to infection was best assessed on the 25 DAl, using lesion length as an index of resistance (IRRI, 2013). The results were presented in Table 1. The donor parent (IRBB7) had a lesion length of about $0.7 \mathrm{~cm}$, indicating the inability of the pathogen to progress in its development in the inoculated tissues of the variety, showing its highly resistant characteristic. The lesion lengths of the 19 BC3F3 lines were less than $5 \mathrm{~cm}$, an almost similar response as IRBB7, thus confirming their resistance (R) to BLB infection. The recurrent parent MR219 and susceptible check variety MR263 were found to be severely affected by the disease. Both varieties were recorded with a lesion length of more than $15 \mathrm{~cm}$ length, which indicates their susceptibility to the disease (S). Meanwhile, the result also showed that two lines without the Xa7gene, the PB-2-32 and PC3-5-2 were having lesion lengths of $12.89 \mathrm{~cm}$ and $12.38 \mathrm{~cm}$, respectively, indicating their moderately susceptible (MS). The results of this experiment confirmed on the successful introgression of $X a 7$ gene into the selected BC3F3 lines, as demonstrated by their high level of resistance to Xoo inoculation. 
Table 1

Lesion length and resistance class of $\mathrm{BC}_{3} \mathrm{~F}_{3}$ progeny lines of the IRBB7 $\times$ MR219 following inoculation with Xanthomonas oryzae pv. oryzae isolate, recorded at $25 \mathrm{DAl}$

\begin{tabular}{|c|c|c|c|c|}
\hline No. & Variety/ lines & R-gene & Lesion length $(\mathrm{cm})$ & Resistance Class* \\
\hline 1 & PB-2-91 & Xa7 & $2.23^{d}$ & $\mathrm{R}$ \\
\hline 2 & PB-2-107 & Xa7 & $2.70^{d}$ & $\mathrm{R}$ \\
\hline 3 & PB-2-156 & Xa7 & $1.86^{d}$ & $\mathrm{R}$ \\
\hline 4 & PB-2-224 & Xa7 & $2.14^{d}$ & $\mathrm{R}$ \\
\hline 5 & PB-2-234 & Xa7 & $2.74^{d}$ & $\mathrm{R}$ \\
\hline 6 & PB-2-238 & Xa7 & $1.24^{d}$ & $\mathrm{R}$ \\
\hline 7 & PB-2-258 & Xa7 & $1.74^{\mathrm{d}}$ & $\mathrm{R}$ \\
\hline 8 & PB-2-29 & Xa7 & $2.19^{d}$ & $\mathrm{R}$ \\
\hline 9 & PB-2-77 & Xa7 & $2.30^{d}$ & $\mathrm{R}$ \\
\hline 10 & PB-2-226 & Xa7 & $1.96^{d}$ & $\mathrm{R}$ \\
\hline 11 & PC-3-26-2 & Xa7 & $1.93^{\mathrm{d}}$ & $\mathrm{R}$ \\
\hline 12 & PC-3-39-3 & Xa7 & $1.69^{d}$ & $\mathrm{R}$ \\
\hline 13 & PB-2-34 & Xa7 & $2.61^{d}$ & $\mathrm{R}$ \\
\hline 14 & PB-2-38 & Xa7 & $2.50^{d}$ & $\mathrm{R}$ \\
\hline 15 & PB-2-150 & Xa7 & $1.43^{d}$ & $\mathrm{R}$ \\
\hline 16 & PB-2-223 & Xa7 & $2.30^{d}$ & $\mathrm{R}$ \\
\hline 17 & PB-2-252 & Xa7 & $0.76^{d}$ & $\mathrm{R}$ \\
\hline 18 & PC-3-14-3 & Xa7 & $1.16^{\mathrm{d}}$ & $\mathrm{R}$ \\
\hline 19 & PC-3-23-1 & Xa7 & $1.79^{\mathrm{d}}$ & $\mathrm{R}$ \\
\hline 20 & PB-2-32 & - & $12.89^{c}$ & MS \\
\hline 21 & PC3-5-2 & - & $12.38^{c}$ & MS \\
\hline 22 & IRBB7 & Xa7 & $0.70^{d}$ & $\mathrm{R}$ \\
\hline 23 & MR219 & None & $16.46^{\mathrm{b}}$ & S \\
\hline 24 & MR263 & None & $18.44^{\mathrm{a}}$ & $S$ \\
\hline
\end{tabular}

\section{Agronomic performances of BC3F4 lines}

The BC3F4 lines which have been confirmed harboring the Xa7gene were planted in the field for the evaluation of their agronomic performance. Their agronomic performance data is presented in Table 2. The study showed significant differences at $(p<0.05)$ in all measurements except for the total number of spikelets per plant and number of filled grains per panicle. However, most of the traits' significance were contributed from the magnitude differences in values of the measured traits between IRBB7 and 216 MR219. 
Table 2

Agronomic characteristics and yield performance of $\mathrm{BC}_{3} \mathrm{~F}_{4}$ progeny lines during the main season of 2019, Seberang Perai Pulau Pinang, research plot

\begin{tabular}{|c|c|c|c|c|c|c|c|c|c|c|c|c|c|}
\hline No & Lines & $\begin{array}{l}\text { R- } \\
\text { genes }\end{array}$ & $\begin{array}{l}\text { No. of } \\
\text { tillers/ } \\
\text { plant }\end{array}$ & $\begin{array}{l}\text { Plant } \\
\text { height } \\
\text { (cm) }\end{array}$ & $\begin{array}{l}80 \% \\
\text { maturing } \\
\text { (days) }\end{array}$ & $\begin{array}{l}\text { No. of } \\
\text { panicle/ } \\
\text { plant }\end{array}$ & $\begin{array}{l}\text { Panicle } \\
\text { length } \\
\text { (cm) }\end{array}$ & $\begin{array}{l}\text { No. of } \\
\text { spikelets/ } \\
\text { panicle }\end{array}$ & $\begin{array}{l}\text { No. of } \\
\text { filled } \\
\text { grains/ } \\
\text { panicle }\end{array}$ & $\begin{array}{l}\text { Percentage } \\
\text { filled } \\
\text { grains/ } \\
\text { panicle (\%) }\end{array}$ & $\begin{array}{l}1000 \\
\text { grains } \\
\text { weight } \\
\text { (g) }\end{array}$ & $\begin{array}{l}\text { Yield/ } \\
\text { plant } \\
\text { (g) }\end{array}$ & $\begin{array}{l}\begin{array}{l}\text { Yield } \\
\text { (kg/ha) }\end{array} \\
\text { CCT }\end{array}$ \\
\hline 1 & $\begin{array}{l}\text { PB-2- } \\
91\end{array}$ & Xa7 & $\begin{array}{l}13.9 \\
a b c\end{array}$ & $96.9^{b}$ & $105.0^{\mathrm{bcd}}$ & $\begin{array}{l}12.0 \\
\text { abcd }\end{array}$ & $24.9^{a}$ & 193.9 & 126.9 & 65.1 & $\begin{array}{l}25.2 \\
\text { bcd }\end{array}$ & $\begin{array}{l}37.7 \\
\text { abcd }\end{array}$ & $7417^{\mathrm{abc}}$ \\
\hline 2 & $\begin{array}{l}\text { PB-2- } \\
107\end{array}$ & Xa7 & $\begin{array}{l}13.1 \\
\text { abcd }\end{array}$ & $94.1^{b}$ & $104.0^{\mathrm{bcd}}$ & $\begin{array}{l}12.4 \\
\text { abcd }\end{array}$ & $23.7^{a}$ & 175.9 & 114.6 & 72.2 & $\begin{array}{l}23.6 \\
\text { def }\end{array}$ & $\begin{array}{l}38.7 \\
\text { abcd }\end{array}$ & $8000^{a}$ \\
\hline 3 & $\begin{array}{l}\text { PB-2- } \\
156\end{array}$ & Xa7 & $\begin{array}{l}14.7 \\
a b\end{array}$ & $\begin{array}{l}92.3 \\
b c\end{array}$ & $101.7^{d}$ & $13.2^{a b}$ & $24.6^{a}$ & 190.7 & 120.2 & 78.5 & $\begin{array}{l}23.9 \\
\text { cdef }\end{array}$ & $48.2^{a}$ & $7000^{a b c}$ \\
\hline 4 & $\begin{array}{l}\text { PB-2- } \\
224\end{array}$ & Xa7 & $\begin{array}{l}13.0 \\
\text { abcd }\end{array}$ & $\begin{array}{l}93.5 \\
b c\end{array}$ & $102.3^{c d}$ & $\begin{array}{l}12.4 \\
\text { abcd }\end{array}$ & $24.4^{a}$ & 170.5 & 123.2 & 72.8 & $\begin{array}{l}24.1 \\
\text { bcdef }\end{array}$ & $\begin{array}{l}37.4 \\
\text { abcd }\end{array}$ & $7250^{\mathrm{abc}}$ \\
\hline 5 & $\begin{array}{l}\text { PB-2- } \\
234\end{array}$ & Xa7 & $\begin{array}{l}13.2 \\
\text { abcd }\end{array}$ & $\begin{array}{l}92.8 \\
b c\end{array}$ & $102.0^{\mathrm{cd}}$ & $12.9^{a b c}$ & $24.0^{a}$ & 175.3 & 123.5 & 70.7 & $\begin{array}{l}24.4 \\
\text { bcdef }\end{array}$ & $\begin{array}{l}39.4 \\
a b c\end{array}$ & $6917^{a b c}$ \\
\hline 6 & $\begin{array}{l}\text { PB-2- } \\
238\end{array}$ & Xa7 & $\begin{array}{l}11.9 \\
\text { bcd }\end{array}$ & $\begin{array}{l}91.6 \\
b c\end{array}$ & $103.7^{\mathrm{bcd}}$ & $11.7^{b c d}$ & $24.1^{a}$ & 177.9 & 123.5 & 67.6 & $\begin{array}{l}24.5 \\
\text { bcdef }\end{array}$ & $\begin{array}{l}34.9 \\
\text { bcd }\end{array}$ & $6583^{b c}$ \\
\hline 7 & $\begin{array}{l}\text { PB-2- } \\
258\end{array}$ & Xa7 & $\begin{array}{l}13.4 \\
\text { abcd }\end{array}$ & $\begin{array}{l}90.8 \\
b c\end{array}$ & $103.0^{\mathrm{bcd}}$ & $13.1^{a b c}$ & $23.7^{a}$ & 188.8 & 123.8 & 69.9 & $\begin{array}{l}24.5 \\
\text { bcdef }\end{array}$ & $\begin{array}{l}41.5 \\
\mathrm{ab}\end{array}$ & $6667^{b c}$ \\
\hline 8 & $\begin{array}{l}\text { PB-2- } \\
29\end{array}$ & Xa7 & $\begin{array}{l}13.1 \\
a b c d\end{array}$ & $\begin{array}{l}92.4 \\
b c\end{array}$ & $102.5^{c d}$ & $\begin{array}{l}12.6 \\
\text { abcd }\end{array}$ & $23.7^{a}$ & 188.6 & 124.1 & 60.8 & $\begin{array}{l}24.5 \\
\text { bcdef }\end{array}$ & $\begin{array}{l}36.7 \\
\text { abcd }\end{array}$ & $6625^{b c}$ \\
\hline 9 & $\begin{array}{l}\text { PB-2- } \\
77\end{array}$ & Xa7 & $\begin{array}{l}13.8 \\
a b c\end{array}$ & $\begin{array}{l}93.2 \\
b c\end{array}$ & $103.0^{\mathrm{bcd}}$ & $13.3^{a b}$ & $24.0^{a}$ & 193.2 & 126.8 & 64.0 & $\begin{array}{l}25.0 \\
\text { bcde }\end{array}$ & $\begin{array}{l}40.5 \\
a b c\end{array}$ & $7000^{a b c}$ \\
\hline 10 & $\begin{array}{l}\text { PB-2- } \\
226\end{array}$ & Xa7 & $\begin{array}{l}13.1 \\
\text { abcd }\end{array}$ & $\begin{array}{l}91.5 \\
\text { bc }\end{array}$ & $104.0^{\mathrm{bcd}}$ & $\begin{array}{l}12.3 \\
\text { abcd }\end{array}$ & $24.9^{a}$ & 187.5 & 123.5 & 62.6 & $\begin{array}{l}24.1 \\
\text { cdef }\end{array}$ & $\begin{array}{l}35.1 \\
\text { bcd }\end{array}$ & $7000^{a b c}$ \\
\hline 11 & $\begin{array}{l}\text { PC-3- } \\
26-2\end{array}$ & Xa7 & $15.4^{a}$ & $\begin{array}{l}90.8 \\
b c\end{array}$ & $105.3 \mathrm{bc}$ & $14.6^{a}$ & $24.1^{\mathrm{a}}$ & 182.6 & 131.6 & 70.7 & $\begin{array}{l}25.4 \\
a b c\end{array}$ & $\begin{array}{l}45.1 \\
a b\end{array}$ & $6667^{\mathrm{bc}}$ \\
\hline 12 & $\begin{array}{l}\text { PC-3- } \\
39-3\end{array}$ & Xa7 & $15.2^{a}$ & $\begin{array}{l}92.2 \\
\mathrm{bc}\end{array}$ & $105.3^{b c}$ & $14.6^{a}$ & $24.6^{a}$ & 168.6 & 131.9 & 62.1 & $\begin{array}{l}25.8 \\
a b\end{array}$ & $\begin{array}{l}35.7 \\
\text { bcd }\end{array}$ & $6250^{\mathrm{cd}}$ \\
\hline 13 & $\begin{array}{l}\text { PB-2- } \\
34\end{array}$ & Xa7 & $\begin{array}{l}13.3 \\
\text { abcd }\end{array}$ & $94.8^{b}$ & $102.3^{\mathrm{cd}}$ & $11.7^{b c d}$ & $24.4^{a}$ & 173.5 & 126.0 & 71.2 & $\begin{array}{l}24.8 \\
\text { bcde }\end{array}$ & $\begin{array}{l}35.9 \\
\text { bcd }\end{array}$ & $7667^{a b}$ \\
\hline 14 & $\begin{array}{l}\text { PB-2- } \\
38\end{array}$ & Xa7 & $\begin{array}{l}13.3 \\
\text { abcd }\end{array}$ & $94.5^{b}$ & $102.7^{c d}$ & $11.8^{\mathrm{bcd}}$ & $24.5^{\mathrm{a}}$ & 185.2 & 126.1 & 67.0 & $\begin{array}{l}24.9 \\
\text { bcde }\end{array}$ & $\begin{array}{l}35.1 \\
b c d\end{array}$ & $7417^{a b c}$ \\
\hline 15 & $\begin{array}{l}\text { PB-2- } \\
150\end{array}$ & Xa7 & $10.6^{d}$ & $\begin{array}{l}92.1 \\
b c\end{array}$ & $103.7^{b c d}$ & $10.1^{\mathrm{cd}}$ & $24.4^{a}$ & 171.3 & 117.3 & 72.3 & $\begin{array}{l}23.8 \\
\text { cdef }\end{array}$ & $28.9^{c d}$ & $6583^{b c}$ \\
\hline 16 & $\begin{array}{l}\text { PB-2- } \\
223\end{array}$ & Xa7 & $\begin{array}{l}14.4 \\
a b\end{array}$ & $\begin{array}{l}90.7 \\
b c\end{array}$ & $104.3^{\mathrm{bcd}}$ & $13.4^{a b}$ & $23.6^{a}$ & 187.3 & 122.7 & 70.0 & $\begin{array}{l}24.0 \\
\text { cdef }\end{array}$ & $\begin{array}{l}44.0 \\
a b\end{array}$ & $6417^{b c}$ \\
\hline 17 & $\begin{array}{l}\text { PB-2- } \\
252\end{array}$ & Xa7 & $10.9^{c d}$ & $94.0^{b}$ & $104.0^{\mathrm{bcd}}$ & $10.1^{d}$ & $24.1^{a}$ & 167.0 & 123.7 & 74.1 & $\begin{array}{l}24.5 \\
\text { bcdef }\end{array}$ & $\begin{array}{l}33.3 \\
\text { bcd }\end{array}$ & $6667^{b c}$ \\
\hline 18 & $\begin{array}{l}\text { PC-3- } \\
14-3\end{array}$ & Xa7 & $\begin{array}{l}13.4 \\
\text { abcd }\end{array}$ & $94.0^{b}$ & $103.3^{b c d}$ & $\begin{array}{l}12.8 \\
\text { abcd }\end{array}$ & $24.4^{a}$ & 182.4 & 127.6 & 69.3 & $\begin{array}{l}25.2 \\
\text { bcd }\end{array}$ & $\begin{array}{l}40.3 \\
a b c\end{array}$ & $7333^{a b c}$ \\
\hline 19 & $\begin{array}{l}\text { PC-3- } \\
23-1\end{array}$ & Xa7 & $\begin{array}{l}13.2 \\
\text { abcd }\end{array}$ & $\begin{array}{l}93.5 \\
b c\end{array}$ & $106.3^{a b}$ & $\begin{array}{l}12.3 \\
\text { abcd }\end{array}$ & $24.2^{a}$ & 182.7 & 128.7 & 67.1 & $\begin{array}{l}25.4 \\
a b c\end{array}$ & $\begin{array}{l}35.9 \\
\text { bcd }\end{array}$ & $7167^{a b c}$ \\
\hline 20 & $\begin{array}{l}\text { PB-2- } \\
32\end{array}$ & - & $\begin{array}{l}12.8 \\
\text { abcd }\end{array}$ & $95.8^{b}$ & $103.0^{\mathrm{bcd}}$ & $\begin{array}{l}12.5 \\
\text { abcd }\end{array}$ & $24.9^{a}$ & 182.1 & 125.2 & 70.2 & $\begin{array}{l}24.7 \\
\text { bcde }\end{array}$ & $\begin{array}{l}40.4 \\
a b c\end{array}$ & $6667^{b c}$ \\
\hline 21 & $\begin{array}{l}\text { PC3-5- } \\
2\end{array}$ & - & $\begin{array}{l}13.1 \\
\text { abcd }\end{array}$ & $94.6^{b}$ & $104.3^{b c d}$ & $11.8^{\mathrm{bcd}}$ & $23.8^{a}$ & 173.5 & 149.6 & 72.9 & $26.9^{a}$ & $\begin{array}{l}35.5 \\
\text { bcd }\end{array}$ & $6417^{b c}$ \\
\hline 22 & IRBB7 & Xa7 & $10.5^{d}$ & $87.2^{c}$ & $98.7^{\mathrm{e}}$ & $10.5^{c d}$ & $21.4^{b}$ & 151.6 & 104.5 & 71.8 & $23.0^{f}$ & $27.1^{d}$ & $5233.33^{d}$ \\
\hline 23 & MR219 & - & $\begin{array}{l}14.5 \\
a b\end{array}$ & $\begin{array}{l}103.0 \\
\mathrm{a}\end{array}$ & $109^{a}$ & $14.0^{a b}$ & $24.7^{a}$ & 167.7 & 108.6 & 76.2 & 23.3 ef & $\begin{array}{l}44.7 \\
a b\end{array}$ & $7417^{\mathrm{abc}}$ \\
\hline
\end{tabular}

Rice variety MR219 has more tiller number (14.5) than IRBB7 (10.5), which consequently exerted more panicle numbers per plant, while the counts of both characteristics for BC3F4 lines were intermediate between both parents. The height of MR219 is $102.96 \mathrm{~cm}$ as compared to the height IRBB7 
$(87.16 \mathrm{~cm})$ while their progenies were mostly intermediate between both parents. The days to $80 \%$ maturity of the BC3F4 lines were ranged between 102 to 106 days, which were shorter than that of MR219 (109 days), but longer than the donor parent (99 days). The plant yield of MR219 is $44.7 \mathrm{~g} / \mathrm{plant}$ as compared to IRBB7 (27.7 g/plant), while most of the BC3F4 lines recorded plant yields which were closer to the plant yield of the recurrent parent, MR219. Plant yield is very much correlated with tiller number per plant $\left(r=0.767^{\star \star}\right)$, panicle number per plant $\left(r=0.0 .760^{\star \star}\right)$, number of spikelet/panicle $\left(0.546^{* \star}\right)$ and number of filled grains/panicle $\left(r=0.707^{* \star}\right)($ Table 3$)$.

Table 3

Simple correlation coefficient analysis for various agronomic characteristics of the $\mathrm{BC}_{3} \mathrm{~F}_{4}$ progeny lines to their yield performance

\begin{tabular}{|c|c|c|c|c|c|c|c|c|c|}
\hline & $\begin{array}{l}\text { Plant } \\
\text { height } \\
\text { (cm) }\end{array}$ & $\begin{array}{l}80 \% \\
\text { maturing } \\
\text { (days) }\end{array}$ & $\begin{array}{l}\text { No. of } \\
\text { panicle/ } \\
\text { plant }\end{array}$ & $\begin{array}{l}\text { panicle } \\
\text { length } \\
\text { (cm) }\end{array}$ & $\begin{array}{l}\text { No. of filled grains/ } \\
\text { panicle }\end{array}$ & $\begin{array}{l}\text { No spikelets/ } \\
\text { panicle }\end{array}$ & $\begin{array}{l}\% \text { Filled } \\
\text { grains }\end{array}$ & $\begin{array}{l}1000 \text { grains } \\
\text { weight }(\mathrm{g})\end{array}$ & $\begin{array}{l}\text { Yield/ } \\
\text { plant } \\
\text { (g) }\end{array}$ \\
\hline No. of tillers & 0.157 & 0.37 & 0.896 ** & $0.410^{*}$ & 0.302 & $0.536^{\star \star}$ & -0.182 & -0.143 &  \\
\hline $\begin{array}{l}\text { Plant height } \\
\text { (cm) }\end{array}$ & & $0.646^{\star \star}$ & 0.166 & $0.599 * *$ & 0.212 & 0.052 & 0.209 & 0.384 & 0.306 \\
\hline $\begin{array}{l}80 \% \text { maturing } \\
\text { (days) }\end{array}$ & & & $0.424^{\star}$ & $0.528 * \star$ & 0.071 & 0.136 & -0.036 & 0.014 & 0.337 \\
\hline $\begin{array}{l}\text { No. panicles/ } \\
\text { plant }\end{array}$ & & & & 0.287 & 0.167 & 0.368 & -0.167 & -0.126 & $0.780^{\star \star}$ \\
\hline $\begin{array}{l}\text { Panicle length } \\
\text { (cm) }\end{array}$ & & & & & 0.314 & $0.481^{*}$ & -0.1 & 0.17 & 0.379 \\
\hline $\begin{array}{l}\text { Filled grains/ } \\
\text { panicle }\end{array}$ & & & & & & $0.485^{\star}$ & $0.612^{\star \star}$ & 0.118 &  \\
\hline $\begin{array}{l}\text { Spikelets/ } \\
\text { panicle }\end{array}$ & & & & & & & -0.393 & 0.098 & $0.546^{\star \star}$ \\
\hline$\%$ Filled grains & & & & & & & & 0.067 & 0.249 \\
\hline $\begin{array}{l}1000 \text { grains } \\
\text { wt. }(\mathrm{g})\end{array}$ & & & & & & & & & 0.189 \\
\hline
\end{tabular}

The yield obtained from the crop cutting test (CCT) may provide a better estimation for potential yields of the generated BC3F4 lines. The yield of IRBB7 is the lowest at $5233.33 \mathrm{~kg} / \mathrm{ha}$ amongst the tested lines, as expected for an imported foreign donor parent, while the yield of the recurrent parent, MR219, a popular rice variety in Malaysia is $7416.67 \mathrm{~kg} / \mathrm{ha}$. The yields of the majority of the improved 21 BC3F4 lines, including those two susceptible lines, were not significantly different from the yield of MR219. This evaluation test showed that the yields of all 19 resistant BC3F4 lines were comparable with the yield of MR219. In addition to that, those lines had been introgressed with the Xa7gene that would ensure their productivity to remain stable even when the BLB epidemic occurs and infecting the susceptible lines or varieties. Interestingly, two lines namely PB-2-107 and PB-2-34 recorded higher yield than MR219, at $8000 \mathrm{~kg} / \mathrm{ha}$ and $7666.67 \mathrm{~kg} / \mathrm{ha}$, respectively.

\subsection{Discussion}

MR219 is an elite rice variety released for cultivation in Malaysia since the year 2001 (Alias et al.,2001). It is widely grown and became the most popular high yielding rice variety in Malaysia (Zainuddin et al., 2012). However, the variety is susceptible to infection by bacterial leaf blight (BLB) disease caused by the pathogen, Xanthomonas oryzae pv. oryzae (Xoo). Increasing incidences of the disease in the fields were reported in recent years, and BLB was classified as one of the major diseases of rice in Malaysia (Chukwu et al., 2019). Infection by the disease could potentially reduce 30-50\% of the crop yield, especially when infection occurred early, as early as at the tillering stage (Shamsudin et al., 2019). Currently, there is no commercial rice variety available in Malaysia that is highly resistant to the disease. Hence, there is a need to improve the resistance to BLB infection among the popular varieties such as MR219 by introducing a resistant gene from a donor parent. A candidate resistant gene, Xa7 was reported to express strong durable resistance against the disease (Kogeethavani et al., 2016). It is a dominant resistant gene, available in an IRRI near-isogenic line IRBB7 (International Rice Research Institute; Accession number 8839) (Chen et al., 2008).

In this study, the resistance expression conferred by the Xa7 was validated by challenging the potential donor parents (IRBB7) with isolate MX01410, a representative of the prevalent Xoo-dominant pathotype through an artificial inoculation. Beside MR219, two other Malaysian commercial varieties namely MR220CL, and MR263 were included. This study observed that BLB symptoms of infection started to emerge as early as 3 days after inoculation (DAI). Symptoms of water soaking up to yellow stripes on the affected blades were observed, Then, the necrotic lesion starting from the leaf tips and gradually increase in length and width with a wavy margin, a similar symptom progression as was reported by Chen et al., (2008) and Majumder et al., (2019). Two commercial varieties, MR219 and MR220CL2 were classified as moderately susceptible while MR263 was as susceptible with lesion length of more than $10 \mathrm{~cm}$ at $25 \mathrm{DAl}$. The donor parent IRBB7, by contrast, has a mild lesion length of less than $5 \mathrm{~cm}$ even after $25 \mathrm{DAl}$. This has confirmed and proved the resistance of IRBB7 as conferred by the presence of the Xa7gene in it. The disease scoring was done at $25 \mathrm{DAl}$ since the previous finding showed that 25 DAl is stage where BLB disease severity (\%) progress stable and consistent (Palson et al., 2017). As shown in Figure 1, the lesion length on MR263 after 25 DAl had started to show a flatter curve. 
To improve the resistance of MR219, we had conducted a series of backcrossing using IRBB7 as the donor parent and MR219 as the recurrent parent. We adopted a marker-assisted selection (MAS) backcrossing in our development project. In MAS, the presence of molecular markers that are closely linked to a gene controlling a specific trait of the plant would allow plant breeders to identify the presence of the gene in the breeding population or lines in the laboratory, that would make selection procedure faster and more accurate, of which is not available in traditional plant breeding technique (Prioul et al., 2017). MAS could help to monitor the transfer of desirable genes from one plant to another such as from parents to their progeny. Two STS markers namely, ID7 and ID15 were used to tag the Xa7gene in the donor parent (IRBB7) because of their closeness to the gene (Zhang et al., 2009). The result shown the polymorphism of marker on parents (Fig. 3). A previous study showed that the genetic similarity of $85 \%$ between the BC3 generation and the recurrent parent could be obtained (Wu et al., 2004). Three cycles of backcrossing is expected to produce BC3F1 individuals with an almost $90 \%$ similarity to the recurrent parent (Fitriah et al., 2019). Selfing activity for another three generations, with MAS at each generation, ensuring the presence of the Xa7gene in selected plants at each generation and we finally managed to generate 19 BC3F4 lines with homozygous Xa7gene. Upon artificial disease inoculation, the 19 BC3F4 lines showed shorter lesion length, comparable to that of the donor parent, which enabled them to be classified as resistant (Table 1), a disease resistance expression as conferred by a dominant Xa7gene.

Agronomic performances evaluation on the 19 BC3F4 lines and parents revealed that at least six characteristics were found to be significantly different between those lines and the donor (IRBB7), while the majority of them had high similarity in characteristics to the recurrent parent (MR219). MR219 was significantly higher in plant height, longer flowering and maturity dates, longer panicle length, and better yield than that of IRBB7. All the 19 BC3F4 lines had high similarity to the characteristics of MR219 which resulted in their better yield performance as compared to the donor parent. This result was anticipated as has been influenced by breeders' preferences during the visual selection process. Higher tiller and panicle numbers/plant, higher spikelet number, and filled grains/panicle have a strong correlation with plant yield obtained. These traits are crucial to contribute significantly to increase rice yield potential (Alias et al., 2001; Fatimah et al., 2014). Among the most potential introgressed lines obtained from the present study were PB-2-107 and PB-2-34. These potential lines were selected because they produced the yield much more superior than MR219 and showed other good agronomic characteristics such as plant height and maturity date which are slightly shorter and earlier than the recurrent parent, MR219. The development of the improved resistant lines will further broaden the genetic resource base of rice and eventually assist further research aimed at increasing the local production of rice. However, the true potential of these lines needs to be further evaluated in advance yield trial tests in multi-locations and sites in the country.

\subsection{Conclusions}

This study showed that the Xa7gene controlling BLB resistance in rice was successfully introgressed by marker-assisted backcrossing into the progenies of a cross involving an elite rice variety, MR219. The introgressed gene confers resistance of BC3F4 lines against the dominant pathotype of BLB causing pathogen in Peninsular Malaysia. Two lines, PB-2-107 and PB-2-34 showed outstanding agronomic performances as well as resistance to the disease.

\section{Declarations Funding}

This research was funded by The Ministry of Energy, Science, Technology, Environment, and Climate Change (MESTECC) with a grant number of TF FP0214B055 (DSTIN).

\section{Acknowledgments}

Special acknowledgements to the Ministry of Energy, Science, Technology, Environment, and Climate Change (MESTECC) with grant numbers of TF FP0214B055 (DSTIN) and Malaysian Agricultural Research and Development Institute (MARDI) staffs for supporting all the research activities.

\section{Conflicts of interest}

The authors declare we have no conflict of interest and the funder had no role in the design of the study, data collection \& analyses, or interpretation of data, writing of the manuscript, or decision to publish the outputs.

\section{References}

1. Alias I, Mohamad H, Othman O, Saad A, Habibuddin H, Azlan S, Lim KH, Guok HP (2001) Pembentukan dan prestasi variety padi baru MR219. MARDI Report No. 196, 8p.

2. Asfaliza R (2019) Rice R\&D @ MARDI. In proceedings of lawatan delegasi Filipina. Kuala Lumpur Malaysia, Malaysia Agriculture Research and Development Institute (MARDI).

3. Chen S, Huang Z, Zeng L, Yang J, Liu Q, Zhu X (2008) High-resolution mapping and gene prediction of Xanthomonas oryzae pv. oryzae resistance gene Xa7. Mol Breeding 22:433-441. 
4. Chukwu SC, Rafii MY, Ramlee SI, Ismail SI, Hasan MM, Oladosu YA, Olalekan KK (2019) Bacterial leaf blight resistance in rice: A review of conventional breeding to molecular approach. Mol. Biol. Rep. 46(1):1519-1532.

5. Cruz CM, Bai J. Ona I, Leung H, Nelson RJ, Mew T, Leach JE (2000) Predicting durability of a disease resistance gene based on an assessment of the fitness loss and epidemiological consequences of avirulence gene mutation. In proceedings of the National Academy of Sciences, 97(25):1350013505.

6. Elixon S, Asfaliza R, Othman O, Siti Norsuha M, Maisarah MS, Alicia J, Shahida H (2017) Evaluation on yield, yield component and physicochemicals of advanced rice lines. J. Trop. Agric. Food Sci. 45(2):131-143.

7. Fatimah F, Prasetiyono J, Dadang A, Tasliah T (2014) Improvement of early maturity in rice variety by marker assisted backcross breeding of Hd2 gene. Indones. J. Agric. Sci, 15(2):55- 64.

8. Fitriah N, Suharsono NS, Suwarna, Miftahudin (2019) Introgression of resistance to blast disease from monogenic line IRBLta2-Re to Ciherang Rice Variety. SABRAO J. Breed. Genet. 51(4): 419-429.

9. Hasan MM, Rafii MY, Ismail MR, Mahmood M, Rahim HA, Alam MA, Latif MA (2015) Marker-assisted backcrossing: A useful method for rice improvement. Biotechnol. Biotechnol. Equip. 29(2):237-254.

10. International Rice Research Institute (IRRI). 2013. Standard evaluation system for rice (SES). Manila, Philippines: 6th Edition, International Rice Research Institute.

11. Jiang N, Yan J, Liang Y, Shi Y, He Z, Wu Y, Peng J (2020) Resistance genes and their interactions with bacterial blight/leaf streak pathogens (Xanthomonas oryzae) in rice (Oryza sativa L.)-an updated review. Rice Sci. 13(1):1-12.

12. Khan JA, Arshad HM, Saleem K, Sandhu AF, Hasnain S, Babar MM (2012) Evaluation of resistance genes in rice against local isolates of Xanthomonas oryzae pv. oryzae in Punjab Province of Pakistan. Arch. Phytopathol. Pflanzenschutz 45(15):1826-1839.

13. Khan MW (2015) Identification of bacterial blight resistance gene Xa7 in rice (Oryzaesativa L.) through STS marker. Int. J. Biosci. 6(2):318-324.

14. Kogeethavani R, Siti Norsuha M, Allicia J, Zamilah A, Nurshamiza MY (2016) Effective resistance genes to bacterial leaf blight disease of rice in Malaysia. In Proceedings of the 9th International Conference on Plant Protection in the Tropics, August 3-5th. Hotel Hilton, Kuching, Sarawak.

15. Lindenthal M, Steiner U, Dehne HW, Oerke EC (2005) Effect of downy mildew development on transpiration of cucumber leaves visualized by digital infrared thermography. Phytopathology 95(3):233-240.

16. Mew TW, Cruz V, Reyes RC (1982) Interaction of Xanthomonas campestris pv. oryzae and a resistant rice cultivar. Phytopathology 72(7):786-789.

17. Ogawa T, Busto G, Tabien R, Romero G, Endo N (1991) Grouping of rice cultivars based on reaction pattern to Philippine races of bacterial blight pathogen (Xanthomonas campestris pv. oryzae). Ikushugaku Zasshi 41(1):109-119.

18. Paslon F, Alovera RB, Amper CD, Ballentes MG (2017) Suppression of bacterial leaf blight (Xanthomonas oryzae pv. oryzae) using local isolates of rhizobacteria. Chiang Mai J. Sci. 21:2-8.

19. Prioul J, Quarrie S, Causse M, Vienne D (1997) Dissecting complex physiological functions through the use of molecular quantitative genetics. J. Exp. Bot. 48(6):1151-1163.

20. Sidhu GS, Khush GS, Mew TW (1978) Genetic analysis of bacterial blight resistance in seventy-four cultivars of rice, Oryza sativa L. Theor. Appl. Genet. 53(3):105-111.

21. Shamsudin NA, Swamy BP, Ratnam W, Crus MT, Raman A, Kumar A (2016) Marker assisted pyramiding of drought yield QTLs into a popular Malaysian rice cultivar, MR219. BMC Genet. 17:30.

22. Shamsudin HS, Muhammad Yaman MA, Ahmad A, Noor Hassim MF (2019) Elucidating the dynamic of drought tolerance rice, MR219-4 to the Xanthomonas oryzae infection. Malays. Appl. Biol. 48(1): 157-162.

23. Siwar C, Idris ND, Yasar M, Morshed G (2014) Issues and challenges facing rice production and food security in the granary areas in the East Coast Economic Region (ECER), Malaysia. Res. J. Appl. Sci. Eng. Technol. 7(4):711-722.

24. Tagami Y, Mizukami T (1962) Historical review of the researches on bacterial leaf blight of rice caused by Xanthomonas oryzae (Uyeda et Ishiyama) Dowson. Special report of the plant diseases and insect pests forecasting service No. 10. Plant Protection Division, Ministry of Agriculture and Forestry, Tokyo, Japan, pp. 112.

25. United States Department of Agriculture (USDA) (2020) Global market analysis. World Agric. Prod. APRIL, pp. 1-33.

26. Webb KM, Ona I, Bai J, Garrett KA, Mew T, Vera Cruz CM, Leach JE (2010) A benefit of high temperature: Increased effectiveness of a rice bacterial blight disease resistance gene. New Phytol. 185:568-576.

27. Wu JL, Sinha PK, Variar M, Zheng KL, Leach JE, Courtois B, Leung H (2004) Association between molecular markers and blast resistance in an advanced backcross population of rice. Theor. Appl. Genet.108(6):1024-1032.

28. Zainuddin, Husein PM, Amirudin M, BadrulHadza A, Marzukhi H, Mohd Bahagia A (2012) Six MARDI popular rice varieties. Buletin Teknologi MARDI 1:1-10.

29. Zhang Y, Wang J, Pan J, Gu Z, Chen X, Jin Y (2009) Identification and molecular mapping of the rice bacterial blight resistance gene allelic to Xa7 from an elite restorer line Zhenhui 084. Eur. J. Plant Pathol. 125(2):235-244.

\section{Figures}




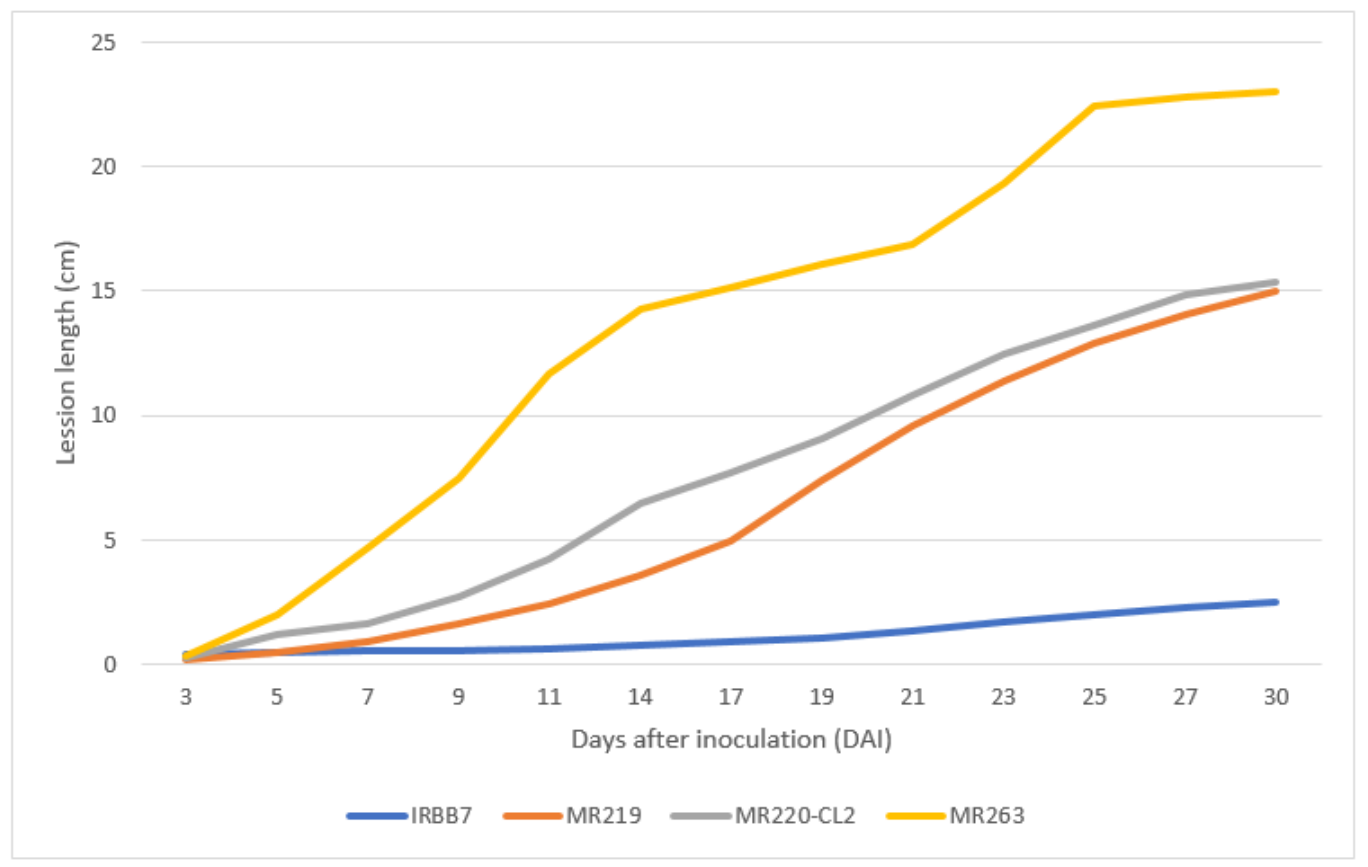

\section{Figure 1}

Progression of lesion length development on the inoculated leaves of four rice varieties (IRBB7, MR219, MR220-CL, MR263) at different days after being inoculated with Xanthomonas oryzae pv. oryzae.


\section{Figure 2}

BLB disease symptom appeared on four inoculated rice leaves varieties following inoculation with Xanthomonas oryzae pv. oryzae observed at 14 DAl. (A) MR263, (B) MR220-CL2, (C) IRBB7 and (D) MR219, respectively. 


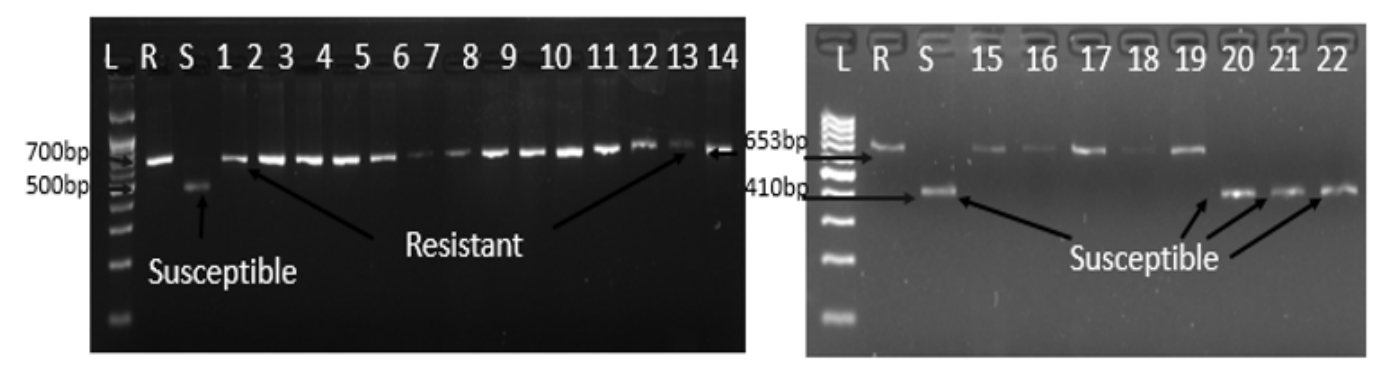

\section{Figure 3}

PCR band of alleles of both parents and BC3F3 lines as amplified by marker ID7, a linked marker to Xa7 gene. Lane L: $100 \mathrm{bp}$ DNA ladder. Lanes R and S represent IRBB7 and MR219 respectively. Description of each lanes are as follows: 1 (PB-2-91), 2 (PB-2-107), 3 (PB-2-156), 4 (PB-2-224), 5 (PB-2-234), 6 (PB-2-238), 7 (PB-2-258), 8 (PB-2-29), 9 (PB-2-77), 10 (PB-2-226), 11 (PC3-26-2), 12 (PC-39-3), 13 (PB-2-34), 14 (PB-2-35), 15 (PB-2-150), 16 (PB-2-223), 17 (PB-2-252), 18 (PC-3-14-3), 19 (PC-3-23-1), 20 (PB-2-32), 21 (PC3-5-2), 22 (MR263). 